ELORE (ISSN 1456-3010), vol. 16 - 2/2009.

Julkaisija: Suomen Kansantietouden Tutkijain Seura ry.

[http://www.elore.fi/arkisto/2_09/kirjallisuus_hovi_1_2_09.pdf]

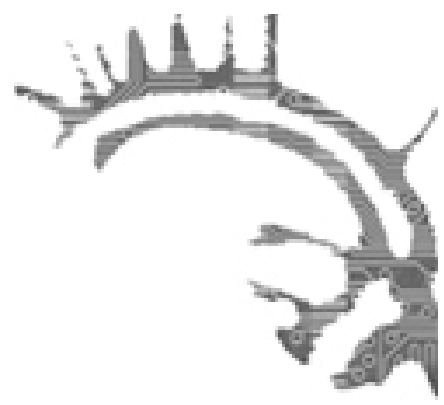

\title{
KIRJA-ARVIO:
}

\section{Puettu ja Riisuttu valta}

Lönnqvist, Bo 2008: Vaatteiden valtapeli. Näkymättömän kulttuurianatomia. Suomentanut Kaisa Haatanen. Helsinki: Schildts. 252 sivua.

\section{$\underline{\text { Tuija Hovi }}$}

Tuoreessa teoksessaan Vaatteiden valtapeli. Näkymättömän kulttuurianatomia etnologi Bo Lönnqvist tutustuttaa lukijansa pukeutumiskulttuurin monimerkityksiseen maailmaan vallan näkökulman kautta. Lönnqvistin teos kritisoi essentialistista valtakäsitystä ja pyrkii laajentamaan itsestään selvän muodollisen vallan käsitettä esittelemällä kätketyn, näkymättömän, symbolisen ja kehittymässä olevan vallan muotoja erilaisissa historiallisissa konteksteissa pukeutumisen kautta. Eksplisiittisen eli ilmeisen vallan ohella yhteiskunnassa vaikuttavat monet implisiittisen vallan muodot, jotka perustuvat esimerkiksi sukulaisuuteen tai myytteihin ja manifestoituvat monin tavoin tapakulttuurissa. Vaatetusta tapakulttuurina voidaan siten tarkastella vallan pukemisena ja riisumisena sekä puettua ja riisuttua ruumista vallan välineenä. Tällä otteella Lönnqvist pöllyttää erityisesti miehen pukeutumista kautta aikojen ja kuorii miehen "paitasilleen" tai tarkemmin sanottuna alushoususilleen. Jonkinlaisena johtomotiivina voi teoksesta löytää kalsarit, jotka näkymättömän vallan - ja vallattomuuden - merkkeinä vilahtavat esiin tuon tuostakin.

\section{MuOdollinen VAlta PUKEUTUMisessa}

Lönnqvistin teosta lukiessa moni itsestäänselvyys sekä mieltä askarruttanut asia avautuu kiinnostavalla, joskus yllättävälläkin tavalla. Erasmus Rotterdamilaista on kiittäminen tai syyttäminen vuonna 1530 ilmestyneestä etikettikirjasta, joka on ilmeisesti viitoittanut eurooppalaisten käytöstä monin tavoin. Asennoituminen omaan ruumiiseen, ulkonäkö sisäisen olemuksen peilinä sekä säädynmukainen käyttäytyminen 


\section{Tuija Hovi}

ja pukeutuminen saivat siinä ohjeistuksensa samoin kuin julkisten virkojen hoito, vallankäyttö ja hyvät tavat. Noihin aikoihin alettiin saada tietoja myös alkuperäiskansojen pukeutumisesta, mikä herätti pohdinnat vaatteiden synnystä ja kehityksestä. Pukeutumisessakin eurooppalaisuus haluttiin nähdä kehityksen ylimpänä muotona, ja eurooppalaisen standardin mukaan arvioitiin muiden kansojen vaatetusta. Pukeutumisen tulkittiin heijastavan suorastaan yhteiskunnan järjestäytyneisyyttä. Näin ollen oli varmasti tilausta tapakulttuurin määrittelylle oppaan muodossa. Erasmuksen neuvojen on myös helppo huomata kertautuvan myöhemmissä käytös- ja pukeutumisoppaissa.

Vaikka kirjan varsinaisena juonena onkin näkymätön valta, näkyvän vallan käyttäjät eli valtiolliset hallitsijat saavat teoksessa paljon huomiota. Monarkit niin Espanjassa, Ranskassa kuin Ruotsissakin tuntuivat tietävän, mitä tekemistä pukeutumisella ja valtaasemalla on keskenään. Mahtipontinen espanjalainen muoti myllynkivikauluksineen omaksuttiin 1500-luvulla Euroopassa ja kuilu hovin ja kansan pukeutumisen välillä syveni. Kuninkaallisissa piireissä miesten puku oli naisten pukua tärkeämpi ja koreampi. Maskuliinisuuden ponteva korostaminen ei rajoittunut pelkkiin kalukukkaroihin. Lönnqvist kertoo esimerkiksi irtovatsan olleen tärkeä miehisen vallan merkki, jota naiset arvostivat. Efekti oli varmasti tehokas, sillä samalla elettiin miesten sukkahousujen kulta-aikaa. Kustaa III:n aikana Ruotsissa kansallisen puvun käyttöönotolla puolestaan tähdättiin poliittisen yhtenäisyyden korostamiseen aikana, jolloin puku ilmaisi lähtökohtaisesti säätyeroja. Kansallinen puku antoi kuitenkin edelleen mahdollisuuksia eriarvoisuuden ilmaisulle esimerkiksi väreissä, yksityiskohdissa ja materiaaleissa. "Yksi kansa, yksi puku" -periaate ei siis toteutunut lähimainkaan samoissa mittasuhteissa kuin vaikkapa Maon Kiinassa.

Ranskan vallankumouksella oli monien muiden asennemaailmaa tuulettavien vaikutusten lisäksi seurauksia myös pukeutumiseen, kun vaatemuoti politisoitui. $\mathrm{Pu}$ kureformin kautta otettiin kantaa valtion tuhlailuun ja haluttiin ilmaista tasa-arvoa sekoittamalla eri säätyjen vaatetusta. Vaatteilla poliittisena valintana, niihin pukeutumisesta tai niiden kieltämisestä kirjoittaja antaa useita esimerkkejä. Autonomian ajan Suomessakin kansallisromantiikan henki ja poliittiset viritykset konkretisoituivat kansallispukuhankkeissa. Lönnqvist viittaa nelivaiheiseen folklorisointiprosessiin, jonka läpi vaatteet mankeloituvat kansallispuvuksi ja välineiksi poliittiseen vallankäyttöön. Suomalaiskontekstissa Sanna-Kaisa Spoof (2003) on esitellyt kansallispukufolklorismia ja yksityiskohtaisemmin Iitin puvun rakentamista.

\section{IDENTITEETTI, USKONTO JA KARNEVALISOINTI}

Uskontotieteilijä Terhi Utriainen on kirjassaan Alaston ja puettu (2006) pohtinut ihmisen suhdetta vaatteeseen ja pukuun erilaisten tekstien kautta juutalais-kristillisessä traditiossa. Hän on tarkastellut pukeutumista toimintana, johon liittyy huoli yksilön alati muuttuvasta ja keskeneräisestä identiteetistä. Lönnqvist käsittelee pukua konkreettisena identiteettivarustuksena, funktiossa, joka on ilmeisimmillään silloin, kun se syystä tai toisesta kielletään. Erilaiset totalitääriset järjestelmät kuten vankila, luostarilaitos, sairaala häivyttävät ihmiseltä hänen minuutensa pukemalla hänet nöy- 
ryyttävällä tai yhdenmukaistavalla tavalla. Minuuden äärimmäisellä tavalla riisuvia keskitysleirikuvauksia analysoituaan Utriainenkin on todennut, että ihminen tarvitsee puvun ollakseen oma itsensä.

Häpeän tunne ja käsitys siitä, mitkä ruumiinosat tulee peittää toisten katseilta, on kelvannut yhdeksi selitykseksi pukeutumisen alkuperästä. Uskonnollisesti perustellut kunnia- ja siveyskäsitykset ovat suorassa suhteessa pukeutumissääntöihin. Kuten Lönnqvist muistuttaa, seemiläinen vartalon peittämisperiaate levisi aikoinaan myös islamiin. Huntukiistaahan puidaan edelleen valtakysymyksenä siitä, onko huntuun pukeutuminen naiselle oikeus vai velvollisuus (ks. Sakaranaho 1998). Kiinnostus vaatteisiin ja koristautumiseen on useimmissa kristillisissä traditioissa yhdistetty syntiin. Tosin kristinuskon kuten muidenkin uskontojen piirissä löytyy äärimmäisyydestä toiseen ulottuvia variaatioita opillisissa suhtautumistavoissa. Apostoli Paavalin naisille suuntaama kehotus pään peittämisestä nöyryyden merkkinä ohitetaan tänä päivänä varsin yleisesti protestanttisissa piireissä. Lönnqvist tulkitsee nykyisen yleisesti ottaen vapaamman suhtautumisen vartaloon ja vaatteisiin liittyvän länsimaiseen sekularisaatioon.

Identiteetin, normien ja vallan parodiointi ja karnevalisointi saa myös lukunsa. Sellaisina kirjoittaja tarkastelee ylioppilaiden kalendaarisia juomarituaaleja, haalarijuhlia. Haalariin pukeutuminen ja viinan läträäminen kääntävät kaiken päälaelleen ja irrottavat arjen normeista pukeutumalla mahdollisimman epäakateemisesti, mutta ei kuitenkaan muuta osallistujien sosiaalista statusta tai mitään muutakaan. Lönnqvist tiivistää lakonisesti: "Haalari on merkki siitä, että tapahtuu jotain merkillistä vaikka mitään ei tapahdu, homogeeninen haalarimassa vain liikkuu humalassa" (s. 155). Toinen viileän analyysin saava irtiottorituaali on Turhapuro-henkinen kalsarikänni, jota Lönnqvist luonnehtii "riisuutumisen kulttuuriseksi muodoksi, jolla mies mitätöi itseään" (s. 158). Sekä yhteisöllisen haalarikännin että ulkopuolisilta suljetun kalsarikännin hän näkee protesteiksi status- ja kulutusyhteiskuntaa vastaan, joskin alkoholin kulutus on kyseisten rituaalien keskeisin sisältö.

\section{Muodin VALta}

Pukeutumiskulttuurin yhteiskunnallisuudesta kertoo se, että vaatteiden historia Euroopassa keskiajalta asti ollut taistelua kristinuskon, kunnia- ja siveyskäsitysten sekä muodin välillä. Muoti paitsi kävi vuoropuhelua politiikan ja uskonnon kanssa, myös vaikutti muotokuvamaalareiden myötä maalaustaiteeseen. Lönnqvist selittää renessanssiajan italialaisen muodin puutetta sillä, että italialaiset mieluummin sovelsivat muita muodin virtauksia kuin kehittivät omaansa. He halusivat välttää liioittelua ja korostaa eleganssia. He eivät siis tarvinneet muotia, koska tiesivät - ja tietävät edelleen - mitä tyyli on, jos ajatellaan, että muoti on sitä mitä tarjotaan ja tyyli on sitä mitä siitä valitaan. Tosin tänä päivänä monet nimekkäät italialaiset muotisuunnittelijatkin ovat niittäneet kansainvälistä mainetta.

Lönnqvist pitää George Simmelin määritelmää muodista toimivimpana: Muoti pakenee määritelmiä ja lokerointia, koska se liikkuu lakkaamatta. Muotia leimaa hetkellisyys. 


\section{Tuija Hovi}

Kun se tavoittaa tavallisen kadunkulkijan, se ei enää ole muotia. Kun Ranskasta alkoi maalaustaiteen myötä kehittyä muodin keskus, muodin luomisen ja taiteen välinen side vahvistui. Tämä side on vahva myös Simmelin 1900-luvun alun näkemyksessä muodista. Muoti toimii samoin kuin taide: se syntyy protestina, pikkuhiljaa se hyväksytään ja siitä tulee normi, joka on jälleen protestina rikottava. Antropologisemmassa katsannossa nykyaikana muodissa voi erottaa kaksi tasoa: taiteen ja kansankulttuurin. Yhtäältä muotisuunnittelijat luovat haute couture -luomuksensa, joista osa kesytetään massatuotantoon sopiviksi prête á porter -mallistoiksi - ja seuraavan sesongin muodiksi. Toisaalta TV-sarjat, rock- ja poptähdet sekä stylistien armeijat viitoittavat suuren yleisön, eli perinteisemmin sanottuna rahvaan, pukeutumisinnovaatioiden suuntaa.

Etnologina Lönnqvist pohtii myös vaatteen museoarvoa ja sitä, kuinka vaatteista tulee arvokkaita antikviteetteja. Puvun kulttiarvoa ei määrää pelkkä muoti tai arvo designtuotteena, vaan sen prestiisiä nostaa yhdistäminen tunnettuun historialliseen henkilöön tai tilanteeseen. Kovinkaan montaa naisten lehteä ei tarvitse selata, kun huomaa myös kombinaation "suunnittelija \& julkkis" olevan mainitsemisen arvoinen asia seurapiirien pukuloistoa vertailtaessa. Käyttäjä antaa vaatteelle hengen.

\section{MERKitYKSIN ASUSTETTU VAATE}

Kalsarikulttuurin tutkimuksessa Lönnqvist lienee varsinainen pioneeri. Hän toteaa vaatetutkimuksen olevan vähäistä nykyaikaisista miesten vaatteista, erityisesti miesten alusvaatteet ovat jääneet vähälle huomiolle. Ruotsissa tietoja miesten alusvaatteiden käytöstä on jo 1560-luvulta. Kirjoittaja arvelee Haminan kadettikoululla 1800-luvulla olleen ratkaiseva vaikutus miesten alusvaatekehittelyyn Suomessa - sinänsä jalostavine karaisuperiaatteineen se hidasti sitä. Ranskalaisittain caleçon, kalsongit eli kalsarit kokivat hänen mukaansa merkittävän siirtymän kohti nykyaikaa, kun Y-front esiteltiin vuonna 1948. Tämän sepaluksen vallankumouksen jälkeen Lönnqvist kertoo suomalaisyrityksen jatkaneen käytännöllisempien ja mukavampien alusvaatteiden kehittelyä periaatteenaan "Hyvon yllä, hyv' on olla". Pian modernit nimettömät kelpasivat jo valtiollisiksi arvolahjoiksi presidentti Kekkosen saunavieraille. Kalsarimuodin katselmus etenee värien ja kuvioiden kulttuurikohtaisuutta sekä mainosten miehisyyden ja seksuaalisuuden korostusta pohtimalla.

Heinäkuussa 2009 radiouutisissa kerrottiin brittitutkimuksesta, jonka mukaan naiset käyttävät keskimäärin 287 päivää elämästään pukeutumisen pohtimiseen. Sillä, mitä päälle pannaan, on siis muutakin merkitystä kuin luonnon olosuhteilta suojautuminen. Uutisissa ei ollut mainintaa miesten pohdintojen määrästä, mutta jos Lönnqvistiä on uskominen, myös miehille pukeutumisessa kutoutuu huoli identiteetistä, joka monin tavoin rakentuu suhteessa valtaan. Ehkä tietynlainen "maastoutuminen" palvelee kuitenkin nykypäivän keskivertomiehen vaatevalintoja. Silmiinpistävänä dandynä ei moni halua esiintyä. Uskottavuudesta vaatetuksella viestinnässä on historian kuluessa tullut lukuisten kulttuuristen tekijöiden summa.

Vaatteiden valtapeli on sivistävä tietokirja teemasta, josta suomalaiset kulttuurien tutkijat eivät ole suuremmin innostuneet. Kuten Bo Lönnqvist kuitenkin osoittaa 
esitellen myös runsasta eurooppalaista vaatetutkimusta, pukeutumisen historiasta ja nykyajasta löytyy paljon yhteiskunnallisesti ja kulttuurisesti kiinnostavaa. Tyylikäs taitto ja paljon puhuva kuvitus kutsuvat selailemaan teosta, mutta antoisaa tietokirjaa lukiessa indeksin puuttuminen on aina yhtä närkästyttävää. Pienikin hakemisto parantaisi kirjan käytettävyyttä. Pukeutumiskulttuurin kentän loputtomasti uusiutuvat ulottuvuudet eri näkökulmien kautta tarkasteltuna kertovat paljon yhteiskunnan kehityksestä, niin näkyvästä kuin näkymättömästäkin.

\section{KirJallisuUs}

SAKARANAHO, TUULA 1998: Complex Other. A Rhetorical Approach to Women, Islam, and Ideologies in Turkey. Helsinki: Department of Comparative Religion, University of Helsinki.

SPOOF, SANNA-KAISA (toim.) 2003: Tiltun kapiot. Iittilänen käsityöperinne. Helsinki: SKS.

UTRIAINEN, TERHI 2006: Alaston ja puettu. Rummïn ja uskonnon ääret. Tampere: Vastapaino.

Filosofian tohtori Tuija Hovi on turkulainen uskontotieteilijä. 